\title{
Investigation of Physicochemical Composition of Sceliphron caementarium (black and yellow mud dauber) Nest
}

\section{Kulkarni, D.S. 四}

Received: 06.04.2019
Revised: 12.05.2020

Accepted: 15.05 .2020

\begin{abstract}
Nests of Sceliphron caementarium (black and yellow mud dauber) were collected from Sant Gadge Baba Amravati University (SGBAU), Amravati campus and analysed for their physicochemical composition. The investigation gave results for the nest as - pH 6.57 , porosity $0.87 \mathrm{mg} / \mathrm{g}$, bulk density1.02g/mL, moisture content $1.01 \%$, total surface area $5.55 \mathrm{~g} / \mathrm{mgI}_{2}$ and total surface charge $1.11 \mathrm{mmolH}^{+} \mathrm{eq} / \mathrm{g}$. Values obtained for the ordinary soil from the campus were $\mathrm{pH}$ 7.82 , porosity $0.75 \mathrm{mg} / \mathrm{g}$, bulk density $1.48 \mathrm{~g} / \mathrm{mL}$, moisture content $2.27 \%$, total surface area $4.76 \mathrm{~g} / \mathrm{mgI}_{2}$ and total surface charge $0.98 \mathrm{mmolH}^{+} \mathrm{eq} / \mathrm{g}$. Higher content of calcium and magnesium were found in nest clay samples as compared to the normal soil, whereas the iodine adsorption number and phosphorus were lower than normal soil.
\end{abstract}

Key Words: Bulk density, Calcium, Magnesium, Moisture, Mud dauber nest, pH

\section{Introduction}

Mud dauber (Insecta: Hymenoptera: Sphecidae) play important roles in the ecosystem functions like predators, herbivores, scavengers and pollinator (Chown et al., 2010). One of the widely distributed sphecid, Sceliphron caementarium (Drury), the black and yellow mud dauber, hunts spiders and builds characteristic mud nests to develop their offspring. S. caementarium female typically build their nests on urban structures like roof tops and walls of houses, offices, schools, and bridges (Evans, 2007). The suitability of the nest site depends on the elements of shelter, on the quality of mud and spider prey (Coville, 1987; Shafer, 1949). Thus, mud dauber nests usually considered as aesthetic pests. Earlier researchers showed that mud wasp builds nest by blending water and a variety of constructing materials like soil clay, plant material with its' saliva (Singh et al., 2017). Velede (1995), described that clay soils are hydrous phyllosilicates of aluminium, along with variable alkaline metals, magnesium, iron, alkaline earths and other cations. Mud dauber collect mud, water to wet it, and regurgitate the mixture with saliva, that serves as an adhesive. The saliva produced from the spittle overlaps and build the mud cells cylindrically over the constructions.

\section{Author's Address}

Department of Zoology, Bharatiya Mahavidyalaya, Amravati E-mail.: deeplaxmi26@rediffmail.com
S. caementarium nests can get very crowded on buildings when left undisturbed for extended periods. This species is thus considered as aesthetic pest for the architecture. Physicochemical characterization of Hymenoptera sphecidae (mudwasp) nest was done by Adie et al. (2013), for their promising use as adsorbent material. For the proper application of the nest material through knowledge of their physicochemical composition is required. Therefore, in the present investigation some physicochemical properties of $S$. caementarium nests were analysed for their possible use, rather than being thrown away after removal as annoying material.

\section{Material and Methods}

Collection of nests and normal soil:

From the walls of various departmental buildings at Sant Gadge Baba Amravati University (SGBAU), Amravati Campus, twenty nest samples of Sceliphron caementarium (black and yellow mud dauber) were collected, using plastic troughs. The normal soil samples were collected around the nearby water bodies like taps, wells, pond. The sample collection was done during September 2018-March 2019.

\section{Physicochemical Characteristic Investigation:}

Analytical grade reagents were used for the physicochemical analysis of mud wasp nests. 
Collected nests were air-dried, some part of the selected nest was removed and ground into fine powder with the help of pestle and mortar and filtered using mesh (2mm). Powdered nest material was carefully preserved in sterile tubes and properly labelled for further investigation at the Department of Zoology, Sant Gadge Baba Amravati University (SGBAU) Amravati. The investigation involved the analysis of the physicochemical composition of wasp nest clay and normal soil.

Determination of pH: In $150 \mathrm{ml}$ beaker, $1.0 \mathrm{~g}$ of $S$. caementarium nest material was added to $100 \mathrm{ml}$ of distilled water. The mixture was stirred constantly about an hour and then filtered on a Whatman filter paper. $\mathrm{pH}$ of the filtrate was determined by a digital $\mathrm{pH}$ meter.

Determination of Porosity: In a graduated tube $1.0 \mathrm{~g}$ nest sample was mixed with $50 \mathrm{ml}$ distilled water and centrifuged in the centrifuge machine at $5000 \mathrm{rpm}$ for 10 minutes. The resulting volume was recorded as $V_{T}$ and the porosity was calculated by using the equation (Adie et al., 2013)

$$
\alpha=V_{W} / V_{T}
$$

where, $V_{W}=$ volume of water taken

$V_{T}=$ volume resulting after the dispersion of mudwasp nest

Determination of bulk density: The tamping method described by Ahmedna, et al. (1997), was used for the determination of bulk density. In a $5 \mathrm{~mL}$ graduated measuring cylinder $2.0 \mathrm{gm}$ of the nest material was placed. Then tap the measuring cylinder until the minimum volume was fully occupied. Then bulk density was calculated by placing the values in the equation.

$$
\rho_{B}(g / m L)=m / V_{\text {min }}
$$

where, $\mathrm{m}=$ mass of mud dauber nest,

$V_{\min }=$ minimum volume of mud dauber in measuring cylinder

Determination of moisture content: It was estimated by the method established by the Association of Official Analytical Chemists (A.O.A.C., 1990).

1. Empty dish with lid is dried at $105^{\circ} \mathrm{C}$ for 3 hours in an oven and then cooled in the desiccator.

2. $3 \mathrm{~g}$ of the sample was spread in the dish with a spatula.

3. The dish was placed in the oven to drying, at $105^{\circ} \mathrm{C}$ for 3 hours.
4. Then, the dish was transferred to the desiccator, with a partially covered lid, to cool. Re-weigh the dish and its dried sample.

Calculation - Moisture $(\%)=(W 1-W 2) \times 100 / W 1$ where: $\mathrm{W} 1$ = weight $(\mathrm{g})$ of sample before drying $\mathrm{W} 2=$ weight $(\mathrm{g})$ of sample after drying

\section{Determination of iodine adsorption number} (IAN): Method followed was described by Okieimen et al., (2007).

1. Slur $0.5 \mathrm{~g}$ portion of the mud dauber nest with extra aqueous solution of $0.05 \mathrm{M}$ iodine in a $250 \mathrm{~mL}$ glass beaker.

2. Swirl the contents vigorously for 10 minutes and then filter it through glass wool impregnated in a funnel.

3. A part of the filtrate was back titrated with a standard thiosulphate solution.

The mass (mg) of iodine used or absorbed per gram of mud dauber nest as obtained in the result is the number of iodine.

\section{Determination of surface area of nest material:}

Surface area (S.A.) was calculated as the inverse of the iodine number Surface Area $=1 /$ IAN .

Determination of titrable surface charge:

The Boehm (1994), titration was used for the determination of titrable surface functional groups.

1. $1.0 \mathrm{~g}$ portion of the mud dauber nest was mixed in $50 \mathrm{~mL}$ of aqueous $0.1 \mathrm{M} \mathrm{NaOH}$ solution with occasional stirring for $12 \mathrm{hrs}$.

2.The slurry was then filtered through a plastic funnel impregnated with glass wool.

$3.10 \mathrm{~mL}$ of filtrate aliquots were added to $15 \mathrm{~mL}$ of standard aqueous $0.1 \mathrm{M} \mathrm{HCl}$ solution and the then resulting solution was titrated back with standard aqueous $0.1 \mathrm{M} \mathrm{NaOH}$ solution. The amount of $\mathrm{NaOH}$ required to neutralize the sample was converted into a titrable negative surface charge by expressing the result as millimoles of $\mathrm{H}+$ ions consumed by excess $\mathrm{OH}$-ion per gram of sample

Mineral Content Test: Nest clay and normal soil samples collected from the SGBAU campus were tested for their mineral contents such as Calcium, Magnesium and Potassium using atomic absorption spectrometer (Model: AA300, M/S Perkin Elmer, USA) in the Central Instrumentation Cell (CIC), SGBAU, Amravati. 


\section{Results and Discussion}

One of the wasp species selected from the diverse group of wasp species in the SGBAU campus was the $S$. caementarium (black and yellow muddauber) for this study. The identification of the wasp nests was based on the available literature (Dvorak and Carpenter, 2010; Das and Gupta, 1989; Evans, 2007; Kim et al., 2014).

For the present study, a total of 20 nests of $S$. caementarium (black and yellow mud-dauber), nests were collected from the walls of the department buildings of SGBAU during September 2018 to March 2019. The collected wasp nests were carefully processed and stored in the laboratory for their physicochemical analysis. The most widely used building material by the mud dauber is clay, a mixture of soil and regurgitated water. The comparative analysis between the nest sample of the mud dauber and the normal soil showed that the nest material was acidic $(\mathrm{pH}$ 6.75) whereas the normal soil was alkaline 7.82 . The moisture content of the mud dauber nest was significantly low, 1.01 $\%$. This means that the mud dauber nest can be stored for a long time without any microbial activity. The bulk density of the nest clay sample was lower than that of normal soil (Table 1).।

Table: 1 Physicochemical characteristic of Sceliphron caementarium (black and yellow mud-dauber) nest-

\begin{tabular}{|l|l|l|}
\hline Parameters & Nest Clay & Ordinary Soil \\
\hline $\mathrm{pH}$ & $6.57 \pm 0.01$ & $7.82 \pm 0.02$ \\
\hline Porosity $(\mathrm{mg} / \mathrm{g})$ & $0.87 \pm 0.01$ & $0.75 \pm 0.02$ \\
\hline Bulk Density $\left(\mathrm{g} / \mathrm{cm}^{3}\right)$ & $1.02 \pm 0.02$ & $1.48 \pm 0.02$ \\
\hline Moisture content $(\%)$ & $1.01 \pm 0.01$ & $2.27 \pm 0.05$ \\
\hline $\begin{array}{l}\text { Total Surface Area } \\
\left(\mathrm{g} / \mathrm{mgI}_{2}\right)\end{array}$ & $5.55 \pm 0.01$ & $4.76 \pm 0.02$ \\
\hline $\begin{array}{l}\text { Total Surface Charge } \\
\left(\mathrm{mmol} \mathrm{H}^{+} \mathrm{eq} / \mathrm{g}\right)\end{array}$ & $1.11 \pm 0.01$ & $0.98 \pm 0.02$ \\
\hline $\begin{array}{l}\text { Iodine adsorption } \\
\text { number }(\mathrm{mmol} / \mathrm{g})\end{array}$ & $0.18 \pm 1.07$ & $0.21 \pm 2.01$ \\
\hline Calcium $(\mathrm{mg} / \mathrm{kg})$ & 07.261 & 05.841 \\
\hline Magnesium $(\mathrm{mg} / \mathrm{kg})$ & 02.254 & 01.832 \\
\hline Potassium $(\mathrm{mg} / \mathrm{kg})$ & 01.094 & 02.053 \\
\hline
\end{tabular}

This means that the nest of the mud dauber is lighter and less dense than the normal soil. The calcium and magnesium composition of the investigated nest sample was found to be high $(07.261 \mathrm{mg} / \mathrm{kg}$ and $02.254 \mathrm{mg} / \mathrm{kg})$ as compared to the normal soil $(05.841 \mathrm{mg} / \mathrm{kg}$ and $01.832 \mathrm{mg} / \mathrm{kg})$.
Instead, the potassium content found to be quite low in nest sample over the normal soil (Table1). From the results it can be deduced that the chemical composition of the adhesive compound used for the construction of mud nests, makes it lighter and stronger than normal soil. The regurgitated mixture of the mud dauber contains a high quality of calcium, magnesium and low potassium content than normal clay soil in the SGBAU campus. Though the composition might vary by location. The investigated mud dauber nests were having the total surface area of $5.55 \mathrm{~g} / \mathrm{mgI}_{2}$ and the surface charge of the nest sample was estimated to be $1.11 \mathrm{gm} / \mathrm{mgI}_{2}$ with porosity $0.87 \mathrm{mg} / \mathrm{g}$. The iodine adsorption number for nest was $0.18 \mathrm{mmol} / \mathrm{g}$ which was slightly greater for the normal soil 0.21 $\mathrm{mmol} / \mathrm{g}$.

\section{Conclusion}

From a physicochemical analysis, it can be concluded that the chemical compound responsible for the strength, lightness, and adhesive properties, of $S$. caementarium nest is the composition of various amounts of calcium, potassium and magnesium. The physicochemical properties observed for $S$. caementarium nest show that it is a compound material that could possibly be used, rather than being thrown away after removal as annoying material.

\section{Acknowledgements}

The cooperation of the department of Zoology, SGBAU, Amravati and the assistance of the technical staff of CIC, SGBAU, Amravati is highly acknowledged.

\section{References}

Adie P.A., Kukwa D., TIkyereve R.E. and Kungur P.D. 2013. Physicochemical Characterization of Hymenoptera sphecidae (mud-wasp) nest. Res. J. Chem. Sci., 3(10): 1-7.

Ahmedna M.S., Clarke S.J., Rao R.M. Marshall W.E. and John M.M. 1997. Use of filtration and buffers in raw sugar colour measurements. Jour. Sci. Food Agric., 75: 109-116.

Association of Official Analytical Chemists 1990. A.O.A.C. Official methods of analysis, 13th edition. Washington D.C, 1-7.

Boehm H.P. 1994. Some aspects of the surface chemistry of carbon blacks and other carbons. Carbon, 3(5): 759-760. 


\section{Kulkarni, D.S.}

Chown, S.A., Hoffmann, T., Kristensen, M., Angilletta, N. and Pertoldi, C. 2010. Adapting to climate change: Aperspective from evolutionary physiology. Climate research. 43: 3-15.

Coville, R.E. 1987. Spider-hunting sphecid wasps. In Nentwig W. (ed). Ecophysiology of Spiders. Berlin; New York: Springer-Verlag. 309-319.

Das B.P. and Gupta V.K. 1989. The social wasps of India and the adjacent countries (Hymenoptera: Vespidae). Oriental Insects Monograph, 11: 1-292.

Dvorak, L. and Carpenter, J.M. 2010. New records of vespid wasps from Yemen with synonymy in Belonogaster (Hymenoptera: Vespidae: Polistinae and Eumeninae). Biologische Beitraege, 42(1): 561-563.

Evans A.V. 2007. National Wildlife Federation field guide to insects and spiders and related species of North America. New York: Sterling Pub. 494 pp.
Kim, D.W., Yeo, J.D. and Kim, J.K. 2014. Revision of the family Sphecidae (Hymenoptera: Apoidea) in South Korea. Entomological Research, 44: 271-92.

Okieimen, F.E., Okieimen, C.O. and Wuana, R.A. 2007. Preparation andcharacterization of activated carbon from rice husks. Jour. Chem. Soc. Nig., 32(1): 126-136.

Shafer, G.D. 1949. The ways of a mud dauber. Stanford, CA: Stanford University Press. 78 pp.

Singh Charan, Sharma Nevadita, Vig Monika and Bhati Jainender. 2017. Study of chemical composition and antimicrobial activity of mud dauber wasps nest soil. International Journal of Development Research, 07 Article ID: 81813 pages.

Velede Bruce (ed.)1995. Origin and Mineralogy of Clays: Clays and the Environment, Springer-Verlag Berlin and Heidelberg GmbH \& Co. 